locomotive to be practical. Of course it will require a considerable volume of water to move a car of ten tons. This can be obtained near the head of Butte Creek if it should prove
desirable to have a flume to the timber of that region, and any volume of water necessary for and down Feather River
could be had at the lower end of the Big. Meadows. Of could be had at the lower end of the Big Meadows. Of
course the flume would have to be constructed with a view of
having the track for the car on the top of its sides, and braced from the outside, so that no ties or cross-pieces would be required on the top of the flume, as that must be left open for
the paddle-wheels to work in. If it should cost as much to build a flume of this kind as it does to lay a rairoad-track, the
advantages would still be in favor of the flume, for the economy of motive power is much greater. Indeed, it is It would also have the advantage of being narrow gauge,
which is an important consideration through a mountain which is an important
country.-Butte Record.

ON THE USE OF TIN AND GOLD COMBINED.

By J. PAetsch, M.D., D.D.S., Berlin, Prussia.

I HAVE frequently seen good operators make gold fillings for very delicate patients, who were compelled to suffer for hours.
I am sure that the same could have been made in much less time, and the teeth have been preserved quite as well-perlaps better-by using tin and gold. I say " perhaps better," because
such a tooth requires, for a gold filling. so much time and so much pressure, that besides the other disad vantages, inflammation may follow. It is not the first requisite that we
should make as fine a piece of workmanship as the goldsmich. Our first task is to preserve the tooth, at the expense of as
little pain and discomfort to the patient as possible. If besides this, we can superadd fine workmanship (as we, fortuately, can do in most cases), so much the better.

In operating with tin and gold (and I beg you to note,
gentlemen, that during the six years I have used these gentemen, that during the six years I have used these
materials combined not one of my patients has ever experienced the slightest pain or trouble from galvanic action), I
have found them a much poorer conductor of heat than gold alone. In the winter season, when my patients have com-
plaines of an uneasy feeling in those teeth that had been filled with gold, they have not complained of those in which the combined metals lad been used, although the latter were
more involved in decay. It was the observation of this fact that led me to put a stratum of tin and gold in the bottom of very deep cavities, where the caries has approached very near
the pulp-eavity ; then build the gold on this as a base. An excellent filling is the result, and the patient does not com-
plain of pain attendant upon changes of temperature in the
moutl. In addition, there is this great advantage: such a
filling can be made in lalf the time that the gold alone would require.

A NEW METHOD OF IMPARTING ARTISTIC FINISH TO PHOTOGRAPHS.

By E. DunMore

THE materials are few and their application easy ; they consist of sandpaper, of various degrees of fineness, card-
board, and glue-that is all. Use them after this fashion: Cut a piece of cardboard somewhat larger than the mounted
proof, upon which glue sandpaper, face up ; and when dry cut out an aperture corresponding exactly in shape and size
with the picture to be operated upon ; make the edges of the with the picture to be operated upon; make the edges of the
aperture smooth and even. This constitutes the mask or aperture smooth and even. This constitutes the mask or
die. Suppose it is a medallion portrait of the usual carte
size you wish to finish: fit the sandpaper mask, face down, on the enamelled side of the portrait, adjusting it so that the
oval picture corresponds with the aperture of the mask.
Place a piece of smooth paper outside for the purpose of printing, scratch on the polished parts, and pass the whole through an ordinary rolling-press, face down. On removal, contact with the sandpaper, and the polish and relief of the smooth portions greatly enlanced by the contact. Various
degrees of fineness may be obtained by slightly shifting the position of the mask, and putting through the press after
each alteration. This is the novelty. Other substances each alteration. This is the novelty. Other substances
besides sandpaper can be used. Probably an engraved metal plate would be better; in fact, almost any textile
fabric, such as net, gauze, lace, etc., is applicable. For my fabric, such, as net, gauze, lace, etc., is applicable. For my mental design, a flat mat surface being as good as any thing,
if not better, for giving value to the polished part.

\section{CONDENSED BEER.}

Mr. Lockwood describes, in the Journal of the Society of
Arts, his patent solid or condensed beer. Beer is taken at its best condition, its alcohol is separated and saved by a metho of gentle distillation in vacuo, and the residue is condensed
in a vacuum-pan, like milk. When finished, it is inclosed in hermetically-sealed packages, the alcohol first being added to it again, and acting as a preservative. The fermentation
which was present in the beer when it was taken is suspend-
ed by the heating, and the condensed beer remains sound in ed by the leating, and the condensed beer remains sound in
this condition, apparently for any length of time, as som exists that has now been kept for nearly two years. Whe re-made by adding water, it is not wort, but real beer, having
all its flavor and alcoloolic strength, and lacking only effervescence, which can be quickly imparted by reviving the suspended fermentation for a short time in order to develop or it is fit to drink immediately, if charged with carbonic acid gas, like aërated water.

AMERICAN CHAPEL, ROME.

THE new American chapel, dedicated to St. Paul, is i
course of erection in Rome, from the designs of Mr. G. E. Street. The clurch consists of nave and aisles, of five bays and stone in alternate courses, stone from Arles being employed for the interior, and travertine for the exterior work. gray marble shafts. The building, which is now roofed in,
is covered with tiles, and the aisles are groined in brick with s covere ribs, and the apse has a semi-dome in brick. The
stone
tower, which will be crowned with a low spire, will measure forty-three metres from the ground to the top of the cross o in the aisles, and single lights in the clerestory, and a large
USE OF PAPER.

OF the $1,300,000,000$ of human beings inlabiting the globe, 00,000,000 of the Mo paper nor writing material of any kind; stalks and leaves of plants ; $10,000,000$ use for graplic pur-
poses tablets of wood; $130,000,000-$ the Persians, Hindoos, Armenians, and Syrians- lave paper made from cotton, while consumption by this latter number is estimated at $1,800,000,000$
consumal pounds, an average of six pounds to the person, which has
ncreased from two and a lalf pounds during the last fifty years. To produce this amount of paper, $200,000,000$ pounds
of woollen rags, $800,000,000$ pounds of cotton rags, besides of woollen rags, $800,000,000$ pounds of cotton rags, besides
great quantities of linen rags, straw, wood, and other materils, are yearly consumed. The paper is manufactured in 3900 The proportionate amounts manufactured of the different kinds of paper are stated to be-of writing paper, $300,000,000$ $400,000,000$ pounds ; and $200,000,000$ pounds of cartoons, bloting paper, etc.

\section{[Baltimore Americall, January 10.]}

WRECK OF THE BALTIMORE AIR-SHIP.

THE Schroeder air-ship, which has been lying in a nearly completed state just beyond Boundary avenue, on the north-
western suburbs, was almost totally destroyed last Thursday gut by the heavy gale which prevailed. The board fencing
surrounding it had been removed to one of the neigliboring yards, and preparations were in progress for stowing away expected to raise sufficient means to arrange for a trial of the invention. On Thursday night the ship was left exposed
upon the broad common, and when the wind came it twisted upon the broad common, and when the wind came it twisted
the big macline into a slapeless mass of irregular wickerbeen great, for the strong iron frame is contorted and strained, and where the slip was secured in the ground the earth has
been torn up for several feet around. The machine is so seriously damaged and strained that it 18 not likely that its
use will be eitlier possible or safe. The wreck was yesterday use will be either possible or safe. The wreck was yesterday
viewed by many persons who were attracted to the place by viewed by many persons who were attracted to
the odd-looking thing as seen from a distance.

\section{[Medical and Surrical Reporter.]}

THE QUESTIONABLE VALUE OF HYPODERMIC

DR. LAFITTE, of Paris, attacks lyypodermic medication, far as the alkaloids are concerned. He says, not the alkaloid, ing pain. Startling cases are mentioned (L' Union Méd., No go, obstinate neuralgia, etc., are instantly relieved by the in and the author consoles limself respecting thes are but few, and the author consoles himself respecting these by the con-
sciousness of not having done any harm, if he did no good.
M. Lafitte now asks himself how the simple water acts, M. Lafitte now asks himself how the simple water acts,
and he throws out the theory that the ultimate nerve filaments are compressed by the water, and, being thus paralyzed,
can no longer convey the sensation of pain. M. Latitte goe the lengtl of maintaining that all the hypodermic injections hitherto performed acted through the agency of the water, and he is very particular in stating that lis operations were
followed by abscesses or any unpleasant symptoms.

New-Bedford Evening Standard.] IRON LIGHTHOUSE.

Mr. EDMUND GRINNELL, of this city, is now finishing at his foundry, on South Water street, an iron lighthouse, to be
erected by the government on a coral reef at sand Key, near
Key West, Florida. The structure, for the building of which Mr. Grinnell has the entire contract, requires the use of 35 tons of wroughti-iron, and 40 tons of cast-iron. It consists of
a keeper's dwelling, surmounted by a tower. The dwelling
is $38 \cdot \mathrm{ft}$ square, and $12 \mathrm{ft}, 6$ in. higl. It contains 7 rooms, is 38 ft. square, and $12 \mathrm{ft} .6 \mathrm{in}$. highl. It contains 7 rooms,
each 12 by $12 \mathrm{ft}$., besides an oil-room. The tower, which rises from the centre of the building, is $96 \mathrm{ft}$. lighl and $8 \mathrm{ft}$. in and the tower of wroughti-iron, securely bolted together. As
and the reef on which the lighthnuse is to be placed is entirely
under water, wrought-iron piles will be driven into the coral, under water, wroughttiron piles will be driven int
from which columns will rise to secure the tower.

\section{SUNSHINE.}

AT a recent meeting of the Meteorological Society, Lon-
don, Dr. J. Mann, President, in the chair, a paper was read "On the Registration of Sunshine," by R. H. Scott,
F.R.S. This paper is on the continuous record of sunshine and rainfall obtained at Kew for September, 1875; the
latter by Beckley's rain.gauge, the former by a method oriThis consists in the use of a splere of glass to con This consists in the use of a sphere of glass to concentrate the
sun's rays, and a strip of cardboard is placed on a frame con-
centric with the splere, and distant from it by its own centric with the sphere, and distant from it by its own focal length. The sun when it shines burns a hole in the card-
board, the length of the trace being regulated by the dura-
tion of the weather.

ON THE CHEMISTRY OF THE URINE.

GALIPE (Pharm. Zeitschrift f. Russland, xIII. 683) uses the following method for the determination of albumen, which is
applicable in the presence of the phospliates or the urates. A test-tube is one third filled with a deep yellow solution of picric acid, and one or more drops of the to-be-tested urine added. If albumen is present, there immediately appears a
sharply-marked white cloud ; upon lieating the liquid, the al-
bumen collects in a lump and floats. The reaction leaves nothen collects in a lump and floats. The reaction leaves
E. Reicliardt, in the same journal, xIV. 45, demonstrates the presence of a body similar to dextrine in albuminous David writes (Bull. de la Soc. de Chem. de Paris, xxirr. 235) of a peculiar urine which decolorizes Fehling's solution, but sessing the sime properties was separated from the urine The death of the patient so limited the supply of the materia
that further investigations were prevented.
Z. B. E.
THE WOOD OF NOAH'S ARK.

IN the ancient Egyptian temples stones have been found aces, and these wooden ties of dove-tail form were inserted about an inch deep. Some of these liave been found quite ld, thus proving the wood to be of the most durable kind which the ark was constructed, and which was a sacred ree in ancient Egypt, though now very rarely found. The
thought occurs why, instead of metal dowels, wooden ones
could not sometimes now be used. Thougl metal ones would could not sometimes now be used. Though metal ones would

\section{CORNISH PUMPING ENGINES.}

THE Mining Journal gives reports of sixteen pumping engines. They consumed 1703 tons of coal, and lifted 12 ,
400,000 tons of water 10 fathoms higl. The average duty of the whole is, therefore, $49,200,000$ lbs., lifted 1 tt. lighl,
by the consumption of 112 lbs. of coal, being a little over seven tentlis of a pound of coal per horse-power.
ser.

COAL-MINES IN RUSSIA DEVELOPED BY AMERICAN LOCOMOTIVES.

A consular report from Russia says: "The first ten locomotives were imported to St. Petersburg in 1872 from the
Baldwin Locomotive Works of Pliladelphia, followed by twenty more from the same firm, and last summer fifty more were contracted for at the Grant Factory, in New.J ersey.
The great moment of this incipient trade will be apparen from the fact that there is an immense field here open for
their import for many generations to come, the railroad lines their import for many generations to come, the railroad lines
to Russia having just begun to develop on a greater scale, to Russia having just begun to develop on a greater scale,
those in operation hardly reaching to 18,000 English miles up
to this day. The small locomotives lieretofore built in Russia, at the rate of 100 to 120 only a year, also those imported fram Germany, France, and Belgium, were all built for con-
sumption of wood for fuel till the agent of the Pliladelphia firm liad brought the attention of the consuming department around the town of Worenesk, in Southern Russia, extending over 180 miles, and that whole regions were abounding
with it in the southern half of the empire, sufficient to feed the locomotives of the whole continent. The American lo-
comotives finally accepted and introduced here, being expressly built for coal consumption only, have led Russian
capital to the development of the now quite numerous coalmines in the district named. On account of the faultless guaranteed to haul on a level 1075 tons, in lieu of those heretofore in use, hauling but 650 to 700 tons, they are much pre-
ferred, as the highler price paid for them - namely, 25,000 silver
roubles apiece, instead of 18,000 to 20,000 silver roubles
paid for those brouglit in from Gernany and Austria, would paid for thicate."

CHALCOPHANITE: A NEW MINERAL SPECIES. Mr. GIDeon E. Moore, Pl..D., describes in the American N. J. The mineral occurs in druses of handsome and lustrous but
minute crystals, and in foliated aggregates lining the walls of the cavities in the matrix, or grouped to stalactitic and plunearly so, to the surface upoin which the crystals are implanted, or, in the stalactitic forms, to the The following figure represents a type of frequent occuranong the more perfect crystals

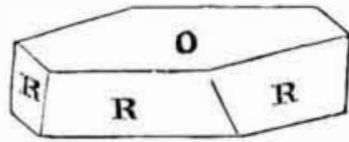
The face 0 possesses a brilliant lustre, and gives perfect
reflections : the rhomboliedral faces are far less brilliant, and are often deeply striated parallel to the basal plane.

The crystals are often flattened out to the thinnest scales,
and these are in some cases rrouped together parallel to 0 , forming aggregates which of ten bear a strong resemblance to combinations between a hexagonal prism and the basal claracter by the alsence of lustre and the frequent strie parallel to the basal plane.
Cleavare : Basal ; perfect. Structure : foliated ; micace1. Thin lamina, very slighitly flexible. Hardness $=2 \cdot 5$. Cuts with a smooth surface like
raphite. Specific gravity $=-3 \cdot 90 \%$. Lustre : metallic; splendent on the basal plane, usually dull on the other faces,
except in the more perfect crystals. Color, bluishl-black, in the larger and more perfect crystals, verging on iron-black.
Streak, clocolate-brown, dull. Opaque even in the thinnest lamellæ.
Before the blow-pipe turns of a color varying from pale Before the blow-pipe turns of a color varying from pale
ellowish bronze to copper-red, exfoliates slighitly, and on continued heating darkens in color, and shows traces of fuoff water and oxygen, exfoliates slightt]y, and changes to a mass of loosely colherent laminæ of a golden-bronze color, and metallic lustre, greatly resembling in appearance certain
varieties of the mineral enstatite (var. bronzite). With borax, a strong manganese reaction, the button becoming cloudy in the reducing flame. On charcoal, with soda and borax, a
coating of oxide of zinc. Soluble in muriatic acid, with evolution of chlorine on warming.
The species is of recent origin, being evidently a product
of the decomposition of franklinite and other manganiferous

THE developments of the Comstock lode in the State of $\mathrm{Ne}$ vada form a special subject to the Director of the Mint in his report lately submitted to the Secretary of the Treasury. A
careful examination of the consolidated Virginia and Citlifornia mines was made by the Director and Prof. R. E. Rogers
in July and August last. The annual product of the Comstork mines is estimated at $\$ 50,000,000$, about 45 per cent of wlich mines is estimated at $\$ 50,000,000$, about 45 per cent of wlich
will be gold : a product equally large from domestic sources may be anticipared during 1876 . Professor Rogers expresses the
opinion that the ore in the two mines above mentioned will opinion that the ore in the two mines above mentioned will
give an ultinate yield of three hundred millions of dollars. 